\title{
Ovary maturation stages histology and follicles diameter of Melanotaenia boesemani rainbowfish ovary from district of North Ayamaru, Maybrat Regency, west Papua
}

\author{
HISMAYASARI, I. B. ${ }^{1,2 *}$, RAHAYU,$S .{ }^{2}$ and MARHENDRA, A. P. W. ${ }^{2}$ \\ ${ }^{1}$ Subrumpun Sumberdaya Genetik dan Konservasi, Program Studi Teknologi Budidaya Perikanan, \\ Akademi Perikanan Sorong, Sorong, Indonésia \\ ${ }^{2} J u r u s a n$ Biologi, Fakultas Matematika dan Ilmu Pengetahuan Alam, Universitas Brawijaya, Malang, Indonésia \\ *E-mail: ib_hismayasari@kkp.go.id
}

\begin{abstract}
Introduction: This research aim is to described ovary maturation stages histologically related with oocytes development in ovary of boesemani rainbowfish M. boesemani from North Ayamaru district, Maybrat Regency, West Papua. Materials and Methods: A histologycal analysis of ovari maturation stage (OMS) of the Boesemani rainbowfish Melanotaenia boesemani performed on 93 ovaries. Fresh ovaries were fixed in 10\% Neutral Buffered Formalin (NBF) and embedded in paraffin. Section of about 5-6 $\mu \mathrm{m}$ thickness were cut and stained with Hematoxylin eosin (HE). Results: Histologycal analysis of rainbowfish M. boesemani ovaries based on oocyte development consist of 8 oocyte types not included atresia follicle i.e oogonia, early perinuclear oocyte, late perinuclear oocyte, cortical alveoli oocyte, early vitelogenic oocyte, mid-vitelogenic oocyte, late vitelogenic oocyte, and mature oocyte. The chorion and follicle layers begins to form at OMS II, keeps growing at OMS III, and was apparent at OMS IV. The chorion and follicle layers at OMS V ovaries were disintegrated. Conclusion: Based on ovary histology, oocyte proportion, and follicles diameter distribution can be concluded that the rainbowfish $M$. boesemani classified as multiple spawner.
\end{abstract}

Keywords: M. boesemani, rainbowfish ovary maturation, rainbowfish ovary histology, rainbowfish oocyte development.

\section{Introduction}

The Boesmani rainbowfish (Melanotaenia boesemani) is an Papua endemic fish and an exotic fish aquarium candidate. The Boesemani rainbowfish M. boesemani is classified into genus of Melanotaenia (CROWLEY and IVANTSOFF, 1982). The Boesemani rainbowfish M. boesemani were found in Ayamaru Lake and several surrounding rivers include Seta, Tiwit and Sagsiger. The Boesemani rainbowfish M. boesemani was recorded in IUCN red list as endangered species (INTERNATIONAL..., 2013). The factors that causing the extinction of this species are generally caused by illegal logging that causes habitats degradation and lacustrine habitats siltation as in some lakes in the bird's head of Papua. The extinction of this species also caused by people catching for ornamental trade (TAPPIN, 2010; ANGFA, 2006) and the used of Derris elliptica that also knows as "akar boreh" to poisoning waters for catching of this species (TAPPIN, 2010). Effort to predominate the decline of its population and increase the number of its natural population can be done with conservation through exsitu reproduction using domestication methods. Knowledge about reproductive biology of domesticated species is one of factor that prescribe the success of domestication.

Reproductive biology is related with ovary and oocyte development in female fish. In general, ovary development stages or ovari maturation stages can be evaluated macroscopically and microscopically. Macroscopic analysis involved ovary observation with naked eyes such as ovary weigth (gonadosomatic index,
GSI), ovaries colour, follicles diameter and another ovaries morphology performance. Microscopic analysis based on ovary histology, oocyte proportion through microscope magnification (MUCHLISIN, 2014; YON, AYTEKIN and YUCE, 2008; SINGH, SINGH, RAM et al., 2008; CASSEL, MEHANNA, MATEUS et al., 2013). Evaluation using both methods give the best description for development of the ovaries (MUCHLISIN, 2014). Analysis of morphological development of the ovaries is often different with histological analysis because ovarian development can not be described accurately (EL-HALFAWY, RAMADAN and MAHMOUD, 2007; FERREIRA, SANTOS, REIS-HENRIQUES et al., 2012; SANTOS, ANDRADE, SANTOS et al., 2005; JAYASANKAR and ALAGARSWAMI, 1994). Ovari maturation stages is related with oogenesis. Oogenesis is dynamic process that occurs in ovary where oocyte through several development stages which is almost the same in teleost fishes (ROCHA and ROCHA, 2006; ABDALLAH and CRUZ-LANDIM, 2003; DE CANALES, BLANCO and SARASQUETE, 1992; KIMARO, 2011; LE MENN, CERDA and BABIN, 2007; YON, AYTEKIN and YUCE, 2008; FERREIRA, SANTOS, REIS-HENRIQUES et al., 2012; LEFLER, HEGYI, BASKA et al., 2008; CASSEL, MEHANNA, MATEUS et al., 2013; JAYASANKAR and ALAGARSWAMI, 1994). Oocyte development stages consist of oogonia, perinuclear oocyte, cortical alveoli oocyte, vitelogenic oocyte, mature oocyte and 
atresia (YON, AYTEKIN and YUCE, 2008; FERREIRA, SANTOS, REIS-HENRIQUES et al., 2012).

Research on reproduction of rainbowfish also done by, Siby (2009), Manangkalagi (2009), Nasution (2008), Crowley and Ivansoff (1982) but only limited in morphology and ovary development. Evaluation of ovary maturation stages histologycally related with oocyte development has not been much done. This research aim is to described ovary maturation stages histologically related with oocytes development in ovary of boesemani rainbowfish M. boesemani from North Ayamaru district, Maybrat Regency, West Papua.

\section{Material Methods}

\subsection{Research material}

A total of 93 ovaries of female Boesemani rainbowfish $M$. boesemani were used in this research. Fish samples was catch using handnet with 2 metre opened and $1 \mathrm{~cm}$ mesh size. Sampling were conducted at North Ayamaru District, Maybrat Regency, West Papua consist of three sampling sites i.e Seta (132 15 ' 17. 215" E and $\left.1^{\circ} 15^{\prime} 64.457^{\prime \prime} \mathrm{S}\right)$, Tiwit (132 $12^{\circ} 99.91 " \mathrm{E}$ and $1^{\circ} 15^{\prime} 45.475 " \mathrm{~S}$ ), Sagsiger (132 15'19.257" E and $1^{\circ} 14^{\prime}$ ' 97.111" S). Sampling sites were determined based on the presence of Boesemani rainbowfish species. Preparation of fish samples were done at Research and Development of Freshwater Fish Aquaculture Installation, Sorong Fisheries Academy, then processed histologically at Pathology and Anatomy Laboratory, Faculty of Medicine, Brawijaya University. All treatment on fish samples have been approved by Animal Care and Use Committee of Brawijaya University No. 135-KEP-UB.

Data taken in this research consist of ovarian maturation stages, oocyte development, the proportion of oocytes in the ovary, and the diameter of the follicles. The data about ovarian maturation stages (OMS), oocyte development, and the proportion of the oocytes were observed from ovary histology. Fresh ovaries were fixed in 10\% Neutral Buffered Formalin $(\mathrm{NBF})$, dehydrated in ascending grades of alcohol start on $70 \%$ until absolute, dealcoholized in xylol and embedded in paraffin. Section of about 5-6 $\mu \mathrm{m}$ thickness were cut and stained with Hematoxylin eosin (HE). Ovarian histology slices were observed using Olyvia version 2.2 software.

Ovari maturation stages consist of OMS I (immature), OMS II (early development), OMS III (developing virgin and resting adult), OMS IV (late developing) and OMS V (gravid) based on ovary development and maturity of rainbowfish. Oocytes development consist of oogonia, perinuclear oocyte, cortical alveoli oocyte, vitelogenic oocyte, mature oocyte, and atresia based on description of Siby (2009), Manangkalagi (2009), Yon, Aytekin and Yuce (2008), . The proportion of the oocytes were counted for determined oocytes cell type distribution in each maturation stages. The proportion of the oocytes determined by comparing the number of oocytes cells with the total number of oocytes were found in ovarian histology slices in the form of percentage (CASSEL, MEHANNA, MATEUS et al., 2013).

The ovaries were used for observation of ovarian follicles diametre is female fish ovaries at OMS III, OMS IV and OMS V. Ovaries were weighed using a balance with 0.001 grams precision and taken a sub-sample i.e anterior, middle, and posterior of the ovaries. The sub samples follicles weigthed, put in petri dish containing water and upright photographed using digital camera (Sony Cyber-Shot DSC-TX66 on same distanc. Photos of follicles sample was observed using Image J $1.42 \mathrm{q}$ software to determine follicles diametre. The data obtained in this research were analyzed descriptively.

\section{Results}

\subsection{Histology of ovarian maturation stages}

Ovari maturation stages of Boesemani rainbowfish M. boesemani were described according to ovary development and maturity of rainbowfish which is consist of OMS I (immature), OMS II (early development), OMS III (developing virgin and resting adult), OMS IV (late developing) and OMS V (gravid). Ovarian histology of rainbowfish $M$. boesemani ovary based on the presence of yolk, nucleus, and nucleoli (SIBY, 2009; MANANGKALAGI, 2009; YON, AYTEKIN and YUCE, 2008.

The first ovary maturation stage of $M$. boesemani rainbowfish reffered OMS I (Figure la). Ovary at OMS I marked with small size of previtelogenic oocytes and contained small amounts of nucleoli. Oocytes development at OMS I ovaries consist of oogonia, early perinuclear oocyte, and late perinuclear oocyte (Figure 2a). Single oogonia have very small size and clear cytoplasm with HE staining (Figure 3a). Oogonia percentage slightly (Table 1) related to very small size that can not be stained by HE. In the center of oogonia cell there is 1 nucleoli and follicles layer have not been observed (Figure 3a). Early perinuclear oocytes also observed in the ovary at OMS I. Early perinuclear oocytes is larger than oogonia. The number of nucleoli in early perinuclear oocytes are between 1-6 and moved at peripheral of nucleus. Basophilic cytoplasm also observed with HE staining (Figure 3b). Late perinuclear oocytes that observed in ovary at OMS I has a size twice larger and more brightly than early perinuclear oocytes. Chromatin material dispersed in nucleus. Cytoplasm looks more basophilic with HE staining. A total of 7-16 small nucleoli were observed in peripheral of nucleus (Figure 3c).

M. boesemani rainbowfish ovary at OMS II (Figure $1 \mathrm{~b}$ ) was characterized with the oocyte that has more larger nucleus. The M. boesemani ovary at OMS II consist of cortical alveoli oocytes (Figure 2b). Cortical alveoli appear at the cytoplasm of cortical alveoli oocyte that looks empty with HE staining. The size of nucleus more larger with increasing number of nucleoli and located very close to the nuclear membrane. Cell wall that consist of chorion and follicular layer begins to formed (Figure 3d).

M. boesemani rainbowfish ovary at OMS III (Figure 1c) was characterized with the appearance of oocytes with yolk granules at surrounding of nucleus. The increasing number of nucleoli were observed at peripheral of the nucleus. Ovary at OMS III consist of early vitelogenic oocyte and mid-vitelogenic oocyte (Figure 2c). The size of early perinuclear oocyte is more larger than cortical alveoli oocyte and the nucleus tends to occupy the center of the cell with multiple nucleoli (Figure 4a). Follicular layers were well developed and can be easily distinguished (Figure 5a). Cortical alveoli in early vitelogenic oocyte replaced by yolk granules at peripheral of cytoplasm that surrounding the nucleus at mid-vitelogenic oocyte. Mid-vitelogenic oocyte has two types of yolk globules, larger yolk globules located at the middle and smallest ones were located at peripheral of cytoplasm (Figure 4b).

The next stage of ovary maturation in M. boesemani rainbowfish ovary is OMS IV (Figure ld). Ovary at OMS IV 

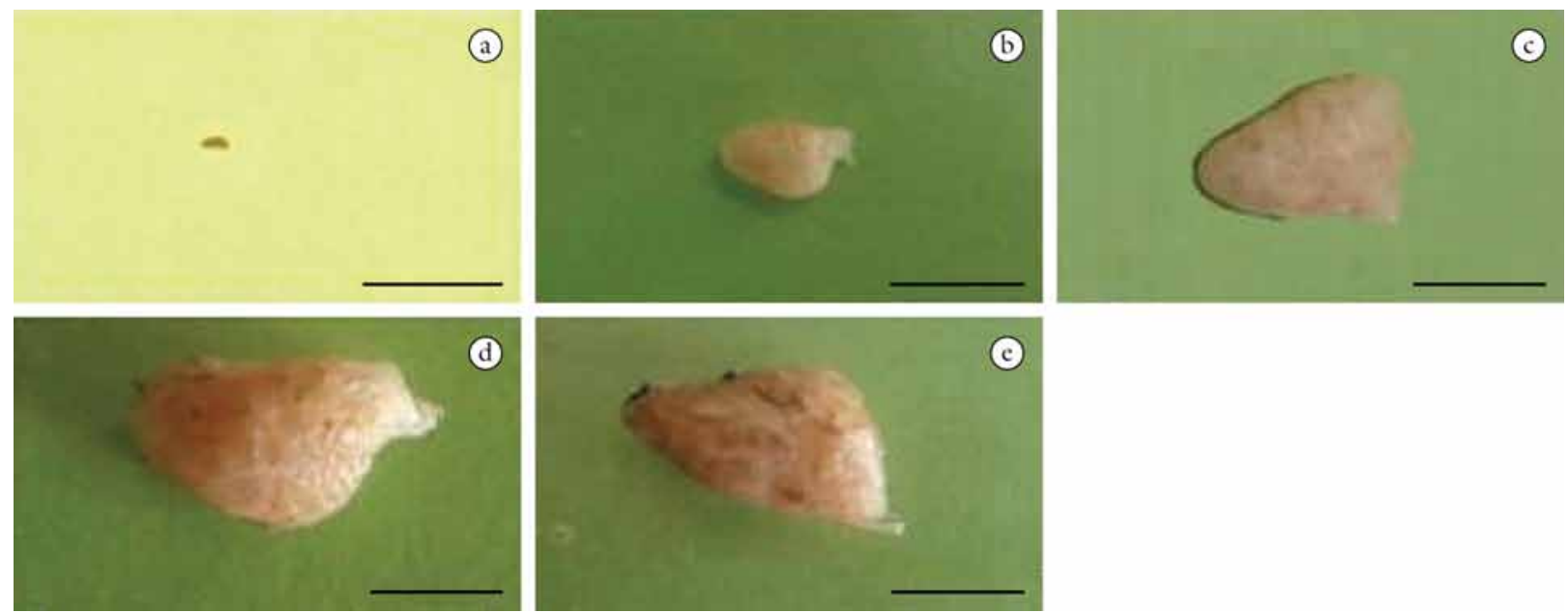

Figure 1. Morphology of M. boesemani rainbowfish ovaries, (a) Morphology of ovary at OMS I, (b) Morphology of ovary at OMS II, (c) Morphology of ovary at OMS III, (d) Morphology of ovary at OMS IV, (e) Morphology of ovary at OMS V ( $1 \mathrm{scale}$ bar = $1 \mathrm{~cm})$.
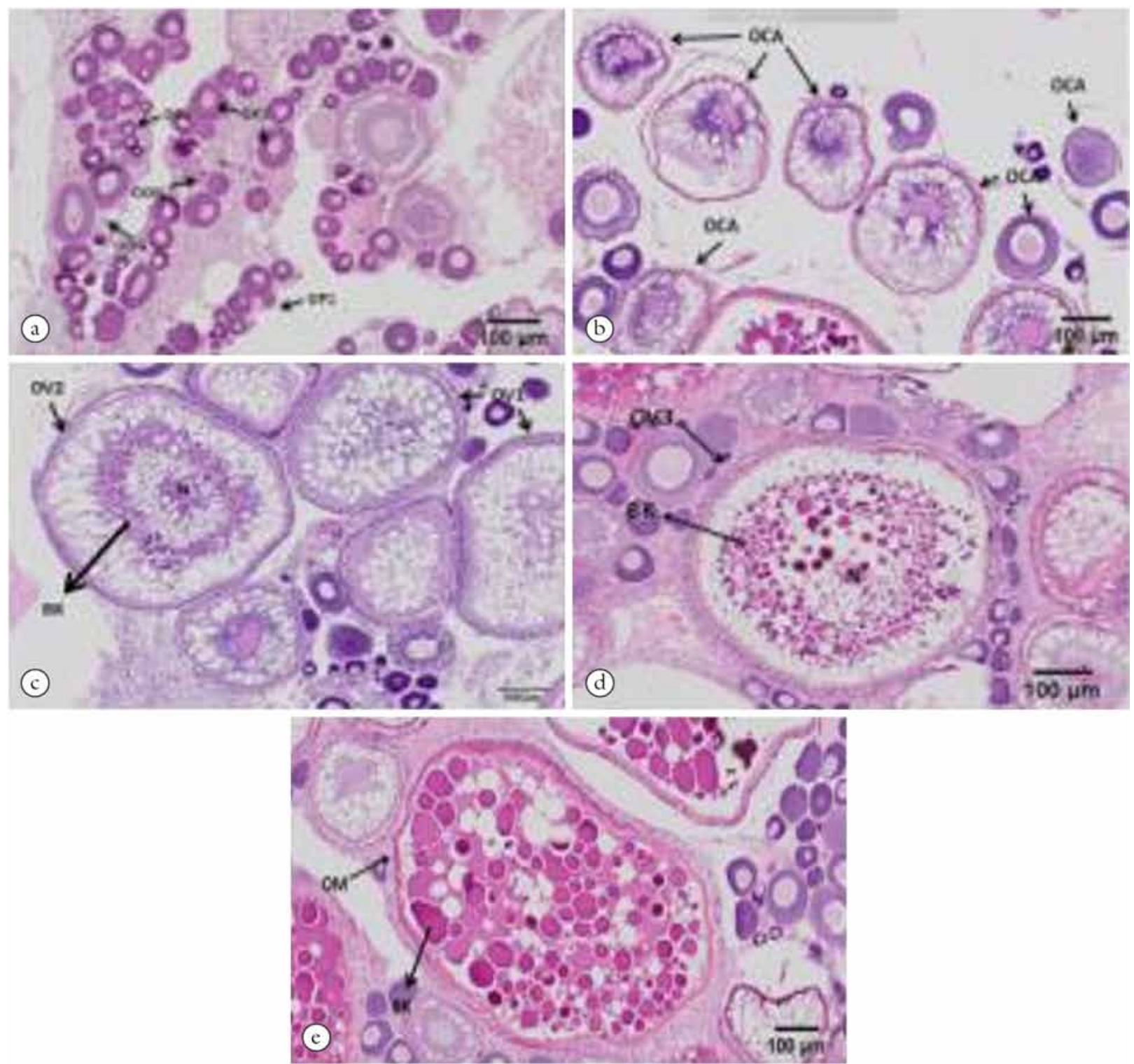

Figure 2. Hystology of M. boesemani rainbowfish ovaries, (a) Hystology of ovary at OMS I, (b) Hystology of ovary at OMS II, (c) Hystology of ovary at OMS III, (d) Hystology of ovary at OMS IV, (e) Hystology of ovary at OMS V (1 scale bar = $100 \mu \mathrm{m})$. 
Table 1. Oocyte proportion in the ovary of $M$. boesemani rainbowfish.

\begin{tabular}{cccccccccc}
\hline \multirow{2}{*}{ Stages } & \multicolumn{10}{c}{ Oocytes proportion (\%) } \\
\cline { 2 - 11 } & OOG & OP1 & OP2 & OCA & OV1 & OV2 & OV3 & OM & AT \\
\hline I & 13.6 & 21.6 & 19.6 & 15 & 10 & 7.6 & 5 & 4 & 3.6 \\
II & 8 & 10.8 & 16 & 21 & 15.4 & 10.4 & 7.6 & 5.8 & 5 \\
III & 0.2 & 6.4 & 9.4 & 15.2 & 20.8 & 16.4 & 12.4 & 12 & 7.2 \\
IV & 0.2 & 3.8 & 5.4 & 8 & 10.6 & 16 & 23.2 & 19.2 & 13.6 \\
V & - & 2.2 & 5.4 & 6.8 & 11.6 & 13.8 & 19 & 24.6 & 16.6 \\
\hline
\end{tabular}

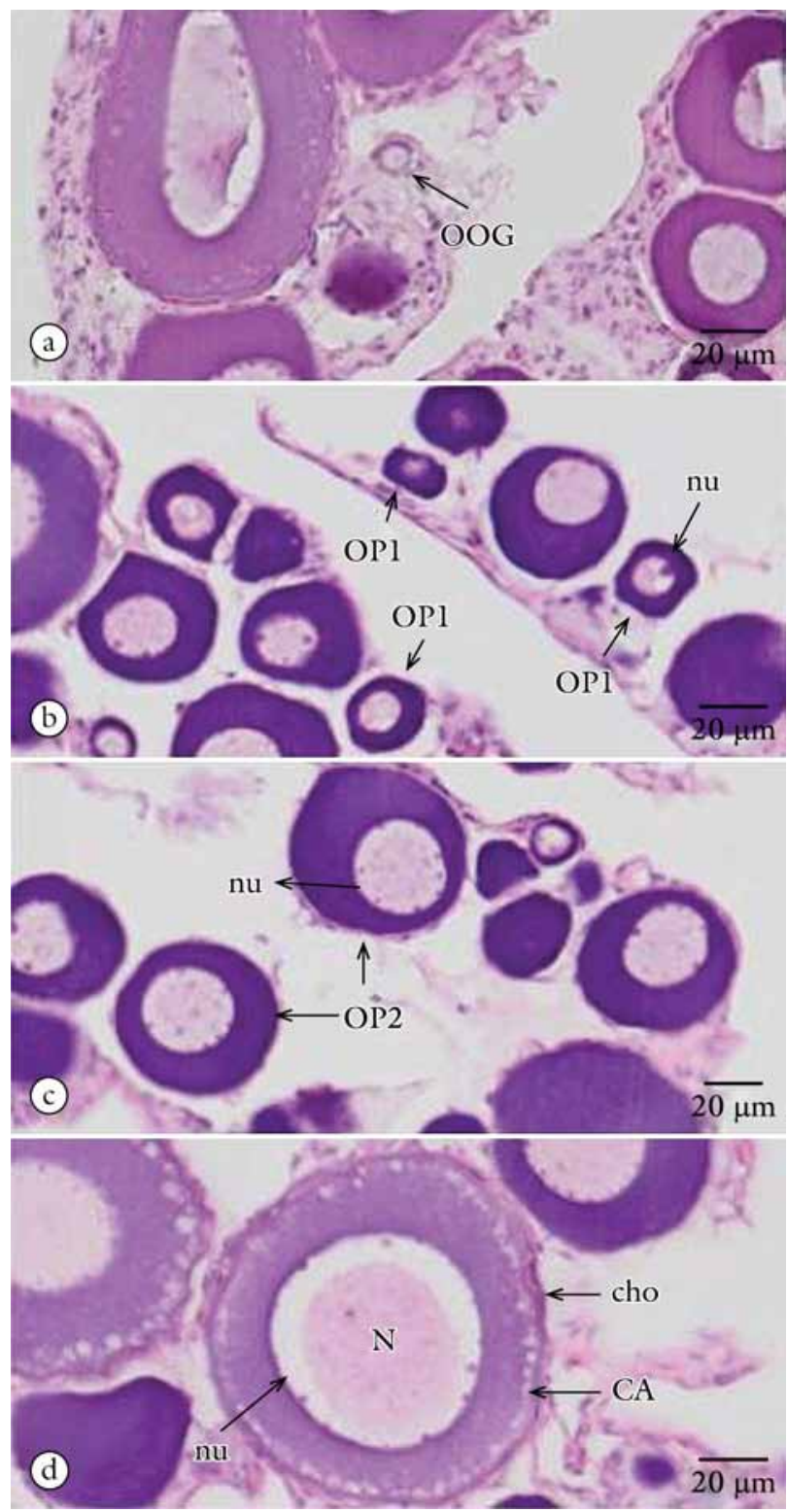

Figure 3. Oocytes at previtellogenic phase (OMS I dan OMS II), (a) oogonia, (b) early perinuklear oocyte, (c) late perinuklear oocyte, (d) cortical alveoli oocyte with chorion and follicular layers (1 scale bar $=20 \mu \mathrm{m})$.

was characterized by oocytes with increase of yolk globules accumulation. Ovary at OMS IV consist of late vitelogenic oocytes (Figure 2d). Cytoplasm of late vitelogenic oocyte are filled with yolk globules accept below of the chorion. The number of yolk globules in late vitelogenic oocyte
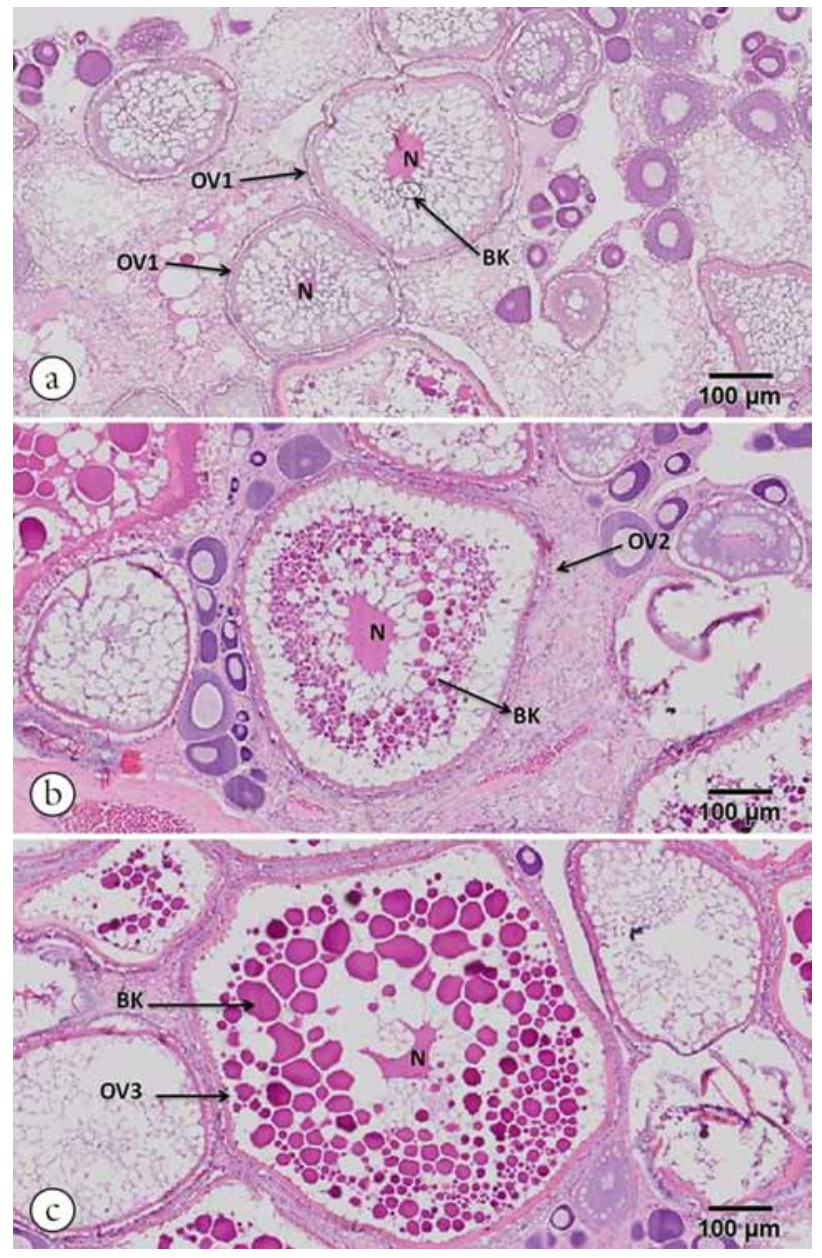

Figure 4. Oocyte at vitellogenic phase, (a) early vitellogenic oocyte (OV1), (b) mid-vitelogenic oocyte (OV2), (c) late vitellogenic oocyte $(\mathrm{OV} 3)(1$ scale bar $=100 \mu \mathrm{m})$.

are increase and has more larger size. Nucleus is located at the middle of the cell with decreasing number of nucleoli (Figure 4c). The chorion and follicular layers were more easily to distinguished (Figure $5 \mathrm{~b}$ ).

The last stage of ovary maturation in $M$. boesemani rainbowfish ovary is OMS V (Figure le). Ovary at OMS V are dominated with oocytes cytoplasm that full filled with yolk globules namely mature oocytes (Figure 2e). The nucleus of mature oocyte can not be observed. The yolk globules in mature oocyte were increased (Figure 6). The chorion and follicle layers at OMS $\mathrm{V}$ ovaries were disintegrating (Figure $5 \mathrm{c}$ ).

Atresia follicles also observed in histologycal analysis of M. boesemani rainbowfish ovary at every ovarian maturation 


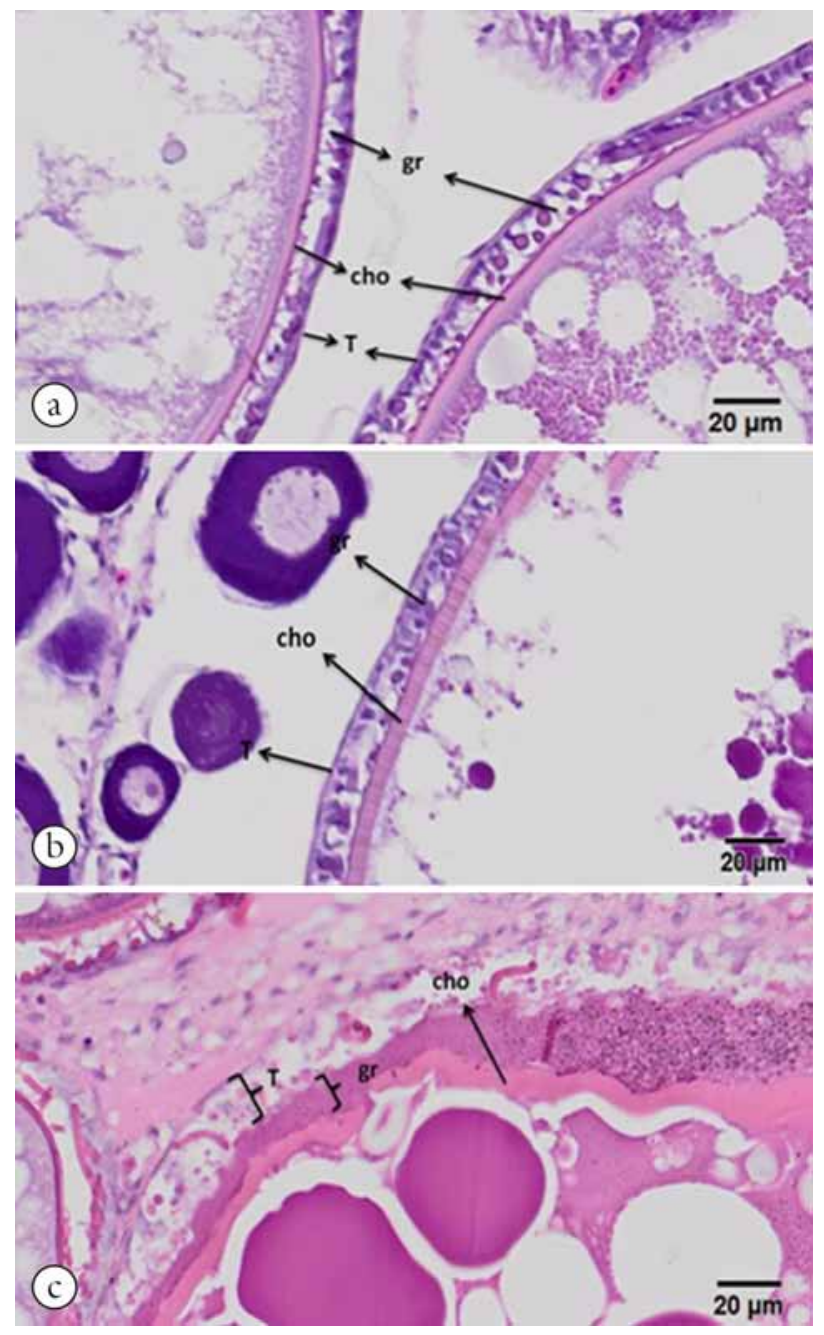

Figure 5. Chorion and follicular layers in M. boesemani rainbowfish oocyte, (a) chorion and follicular layers in OMS III oocyte, (b) chorion and follicular layers in late vitellogenic oocyte, (c) chorion and follicular layers in mature oocyte ( 1 scale bar $=20 \mu \mathrm{m})$.

stages. The proportion of atresia follicles at OMS III (7.2\%), OMS IV (13.6\%), OMS V (16.6\%) higher than atresia follicles proportion at OMS I (3.6\%) and OMS II ovaries (5\%) (Table 1 , Figure 7). Atresia follicles in M. boesemani rainbowfish ovaries were characterized with chorion disintegration (Figure 8a, 8c), hypertrophy of granulose formed like fiber (Figure 8b), irregular shapes of follicles (Figure $8 \mathrm{~d}$ ) due to reabsorption and degeneration, the gap between component of cytoplasm and chorion (Figure 8e).

Analysis of oocytes proportion in the ovaries of M. boesemani rainbowfish showed that previtellogenic cells (oogonia, early perinuclear oocytes, late perinuclear oocyte) in the OMS $\mathrm{I}$ ovaries $(\mathrm{OOG}=13.6 \%, \mathrm{OPl}=21.6 \%, \mathrm{OP} 2=19.6 \%$, $\mathrm{OCA}=15 \%)$ and OMS II ovaries (OO $=8 \%, \mathrm{OPl}=10.8 \%$, $\mathrm{OP} 2=16 \%, \mathrm{OCA}=21 \%)$ have larger proportion than previtellogenic cells in the OMS III ovaries $(\mathrm{OOG}=0.2 \%$, $\mathrm{OPl}=6.4 \%, \mathrm{OP} 2=9.4 \%, \mathrm{OCA}=15.2 \%)$, OMS IV ovaries $(\mathrm{OOG}=0.2 \%, \mathrm{OPl}=3.8 \%, \mathrm{OP} 2=5.4 \%, \mathrm{OCA}=8 \%)$, and OMS V ovaries $(\mathrm{OP1}=2.2 \%, \mathrm{OP} 2=5.4 \%, \mathrm{OCA}=6.8 \%)$. Proportion of vitellogenic cells (early vitellogenic oocytes,

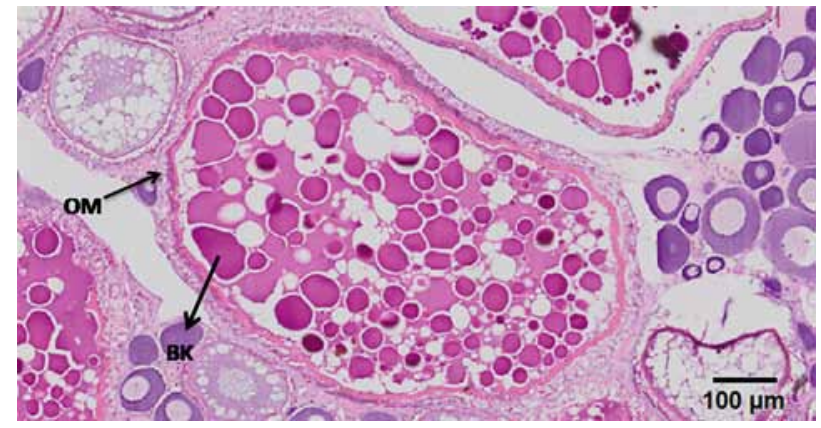

Figure 6. Mature oocyte, there was no nucleus observed and increasing size of yolk globules.

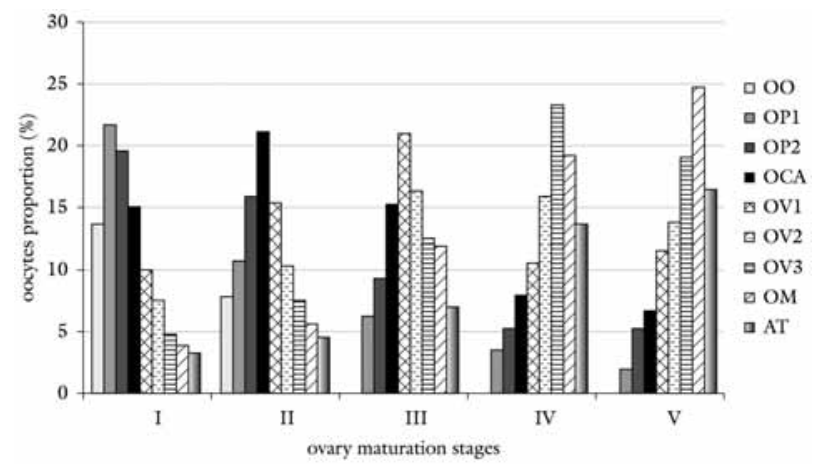

Figure 7. Proportion of oocytes in the ovary of $M$. boesemani rainbowfish $(\mathrm{OOG}=$ oogonia, $\mathrm{OPl}=$ early perinuclear oocyte, $\mathrm{OP} 2$ = late perinuclear oocyte, $\mathrm{OCA}=$ cortical alveoli oocyte, $\mathrm{OVl}=$ early vitellogenic oocyte, OV2 = mid-vitellogenic oocyte, OV3 = late vitelllogenic oocyte, $\mathrm{OM}=$ mature oocyte, $\mathrm{AT}=$ atresia follicle).

mid-vitellogenic oocytes, late vitellogenic oocytes) at OMS III $(\mathrm{OVI}=20.8 \%, \mathrm{OV} 2=16.4 \%, \mathrm{OV} 3=12.4 \%, \mathrm{OM}=12 \%), \mathrm{OMS}$ $\mathrm{IV}(\mathrm{OVI}=10.6 \%, \mathrm{OV} 2=16 \%, \mathrm{OV} 3=23.2 \%, \mathrm{OM}=19.2 \%)$, OMS V ovaries $(\mathrm{OVI}=11.6 \%, \mathrm{OV} 2=13.8 \%, \mathrm{OV} 3=19 \%$, $\mathrm{OM}=24.6 \%)$ have larger proportion than vitellogenic cell at OMS I $(\mathrm{OVI}=10 \%, \mathrm{OV} 2=7.6 \%, \mathrm{OV} 3=5 \%, \mathrm{OM}=4 \%)$ and OMS II ovaries $(\mathrm{OVI}=15.4 \%$, OV2 $=10.4 \%, \mathrm{OV} 3=7.6 \%$, $\mathrm{OM}=5.8 \%)($ Table 1$)$.

\subsection{Follicles diameter}

Analysis of follicles diameter size at OMS III ovaries have highest proportion at $0.58-065 \mathrm{~mm}$ in diameter size. Follicles diameter at OMS IV ovaries have highest proportion at 0.98-1.05 mm in diameter size. Follicles diameter at OMS V ovaries have highest proportion at $1.06-1.13 \mathrm{~mm}$ in diameter size. Based on analysis of follicles diameter noted that follicles at OMS III ovaries have smaller size than follicles at OMS IV and OMS V ovaries. It's also noted that follicles at OMS IV have smaller size than follicles at OMS V. Based on follicles diameter distribution noted that there is 1-3 modus of follicles diameter (Figure 9). Modus of follicles diameter at OMS III ovaries were between $0.58-0.65 \mathrm{~mm}(19.43 \%)$, modus of follicles diameter at OMS IV ovaries were between $0.66-0.73 \mathrm{~mm}$ (6.22\%) and 0.98-1.05 $\mathrm{mm}(20.17 \%)$. The modus of diameter follicles at OMS V ovaries were between 74-0.81 mm (6.26\%), 1.06-1.13 mm (22.04\%) and 1.30-1.37 (9.74\%). 


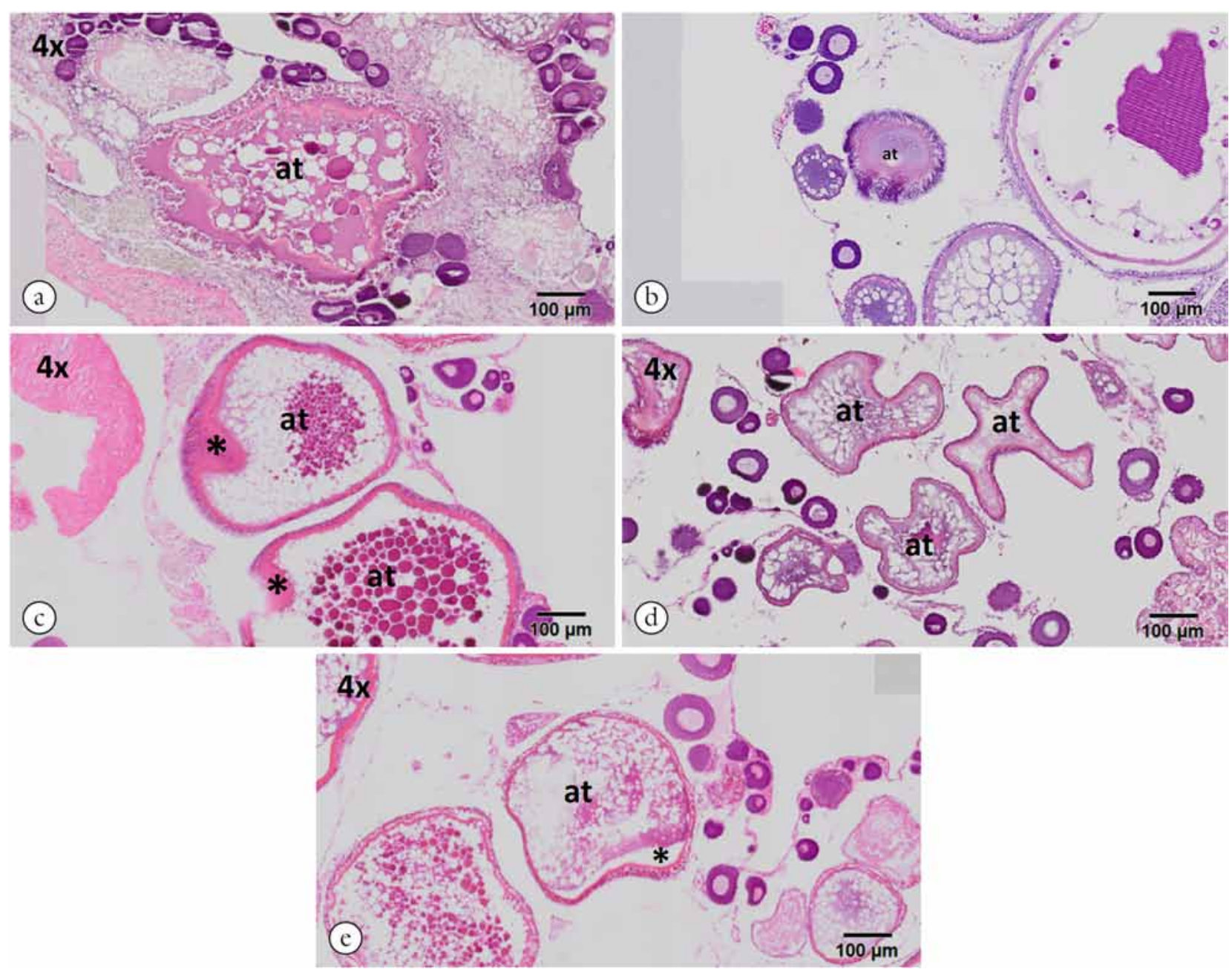

Figure 8. Atresia follicles in M. boesemani rainbowfish ovaries. (a) and (c) chorion disintegration, (b) hypertrophy of granulose formed like fiber, (d) irregular shapes of follicles (e) reabsorption and degeneration, the gap between component of cytoplasm and chorion. (at $=$ atresia follicle,$\left({ }^{*}\right)$ explained atresia characteristics, 1 scale bar $\left.=100 \mu \mathrm{m}\right)$.

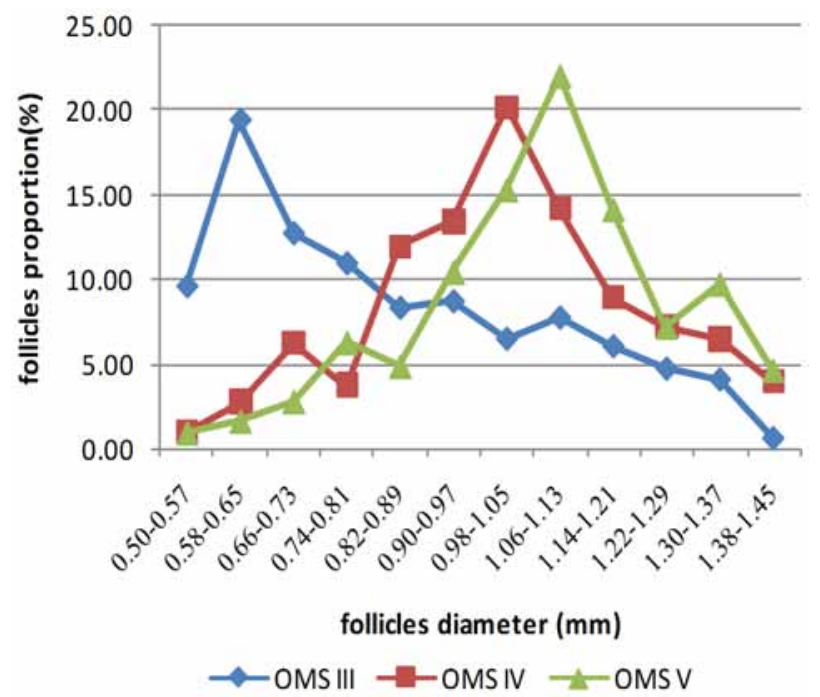

Figure 9. Follicles diameter distribution in M. boesemani rainbowfish ovaries.

\section{Discussions}

Histologycal analysis of $M$. boesemani rainbowfish ovaries based on oocytes development consist of 8 oocyte types not included atresia follicle i.e oogonia, early perinuclear oocyte, late perinuclear oocyte, cortical alveoli oocyte, early vitelogenic oocyte, mid-vitelogenic oocyte, late vitelogenic oocyte, and mature oocyte. The same finding with this results were observed by Yon, Aytekin and Yuce (2008), Ferreira, Santos, ReisHenriques et al. (2012), Lefler, Hegyi, Baska et al. (2008), Cassel, Mehanna, Mateus et al. (2013), Jayasankar and Alagarswami (1994). According to Le Menn, Cerda and Babin (2007), Rocha and Rocha (2006), Yon, Aytekin and Yuce (2008), Lyman-Gingerich and Pelegri (2007), ovary maturation stages consist of previtellogenic phase include primary growth phase (OMS I) and secondary growth phase (OMS II), vitellogenic phase (OMS III) and late growth phase (OMS IV and OMS $\mathrm{V})$. The result of this study primary growth phase decribed by oogonia, early perinuclear oocyte, and late perinuclear oocyte. Some researchers classify oogonia in primary growth phase (ABOU-SEEDO, DADZIE and AL-KANAAN, 2003; EL-HALFAWY, RAMADAN and MAHMOUD, 2007) but 
some doesn't (BAZZOLI and RIZZO, 1990; YON, AYTEKIN and YUCE, 2008). Increased of the number of nucleoli in nucleus of early and late perinuclear oocytes were observed. The same pattern also observed in oocytes of Acanthoparus latus (ABOU-SEEDO, DADZIE and AL-KANAAN, 2003). According to Garcia, Chini, Maistro et al. (2001) the number of nucleoli related with the increasing of RNA synthesis which is useful for oocytes development process.

Secondary growth phase was described by the appearance of cortical alveoli oocytes. Cortical olveoli oocytes has not contained exogenous yolk and there's vacuola at peripheral cytoplasm. Cortical alveoli contained glycoprotein were synthesis by oocyte itself namely yolk vesicles or endogenous yolk (DE CANALES, BLANCO and SARASQUETE, 1992). Material of cortical alveoli released to the surface of oocyte and caused restructure of protein oocyte envelope then formed chorion. According to Bazzoli and Rizzo (1990), cortical alveoli plays a role in fertilization process associated with chorion to preclude a polisperm.

The next phase of oocyte development called vitelogenic phase. Vitellogenic phase is phase that accumulation of exogenous vitellogenin occurred. Vitellogenic phase in M. boesemani rainbowfish ovaries are described by early vitelogenic oocyte and mid-vitellogenic oocyte then keeps growing becomes late vitelogenic oocyte. Late vitellogenic oocyte grow to mature oocyte which is contained yolk globules that fulfilled the oocyte cytoplasm.

Atresia follicles that appear on ovaries of $M$. boesemani rainbowfish can also be found in some teleost fishes such as Oncorbynchus mykiss (SHARMA and BHAT, 2014), Danio rerio (YON, AYTEKIN and YUCE, 2008), Lipophrys pholis (FERREIRA, SANTOS, REIS-HENRIQUES et al., 2012), Melanorivulus aff. punctatus (CASSEL, MEHANNA, MATEUS et al., 2013), Sillago sibama (JAYASANKAR and ALAGARSWAMI, 1994). Atresia follicles found in every maturation stage of $M$. boesemani rainbowfish and more frequent at vitellogenic ovaries but also found in previtellogenic ovaries (Table 1). Folikel atresia pada ikan Pelangi M. boesemani terdapat pada setiap tingkat kematangan ovari dan lebih banyak ditemukan pada ovari vitelogenik tetapi juga ditemukan pada tahap previtelogenik (Tabel 1). This finding was appropriated with the study in Melanorivulus aff. punctatus ovaries (CASSEL, MEHANNA, MATEUS et al., 2013) and Oligosarcus hepsetus (SANTOS, ANDRADE, SANTOS et al., 2005) which stated that atresia follicles found in every stages of ovary maturation. The proportion of atresia follicles were fewer at previtellogenic phase and found more frequent at vitellogenic phase also can be found in ovaries of Carassius auratus dan Oncorbynchus mykiss. It is indicated that apoptosis prosess are involved to normal development ovary and post ovulation in teleost fishes. The proportion of atresia follicles that more frequent in vitellogenic ovaries related with energy conversion that occur in oocytes with more vitellogenin content. However, according to the research conducted by Jayasankar and Alagarswami (1994) and Assem and El-Zaeem (2005) was stated that atresia follicles not found in previtellogenic phase. According to Levani-sivan, Vaiman, Sachs et al. (2004) atresia caused by several factors such as overproduction, excessive concentrations of heavy metals and spawning success. Atresia occurred when oocyte can not grew and failed to spawn then reabsorbed into the ovaries (AROCHA, 2002).
Every oocytes development stage was found in each maturation stages of the $M$. boesemani rainbowfish ovaries based on histologycal analysis. It is indicated that M. boesemani rainbowfish classified as multiple spawner. The result of this study appropriate with research was conducted by Lefler, Hegyi, Baska et al. (2008) and Cek, Bromage, Randall et al. (2001) which is stated that multiple spawner can be indicated on the visibility of all stage of development of the oocytes at each ovary maturity stages. The type of spawning also can be indicated based on follicles diameter distribution with several modus. Multiple spawner fishes secreted mature follicles more than once ovulation and also can be indicates that there is more than one group of mature follicles (MANANGKALAGI, 2009; SIBY, 2009). Based on follicles diameter distribution of $M$. boesemani rainbowfish there is more than one modus explained that the M. boesemani rainbowfish classified as multiple spawner. The same indication seen on ovary of $M$. arfakensis rainbowfish (MANANGKALAGI, 2009) which is stated that this rainbowfish classified as multiple spawner based on follicles diameter distribution where there is more than one modus. The similar finding also found in research conducted by Siby (2009) on ovary of Glossolepis incisus rainbowfish which is stated that several modus in follicles diameter distribution indicates multiple spawner.

\section{Conclusions}

The research about ovary maturation stages in M. boesemani rainbowfish can be concluded that ovary maturation in $M$. boesemani rainbowfish similar with another teleost fishes. The chorion and follicle layers begins to form at OMS II, keeps growing at OMS III, and was apparent at OMS IV. The chorion and follicle layers at OMS V ovaries were disintegrating. Based on ovary histology, oocyte proportion, and follicles diameter distribution can be concluded that the M. boesemani rainbowfish classified as multiple spawner.

Acknowledgements: The authors would like to thanks Dedy Sutendy, Saidin, and all colleagues for precious assistance during fish sampling. We would also like to thanks Ministry of Marine Affairs and Fisheries for scholarship and research funding.

\section{References}

ABDALLAH, FC. and CRUZ-LANDIM, CD. Some Histologycal and Ultrastructural Aspect of Oogenesis in Piaractus mesopotamicus, 1887 (teleostei). Brazilian Journal of Morphological Sciences, 2003, vol. 20 , p. 3-10.

ABOU-SEEDO, F., DADZIE, S. and AL-KANAAN, K. Histology of ovarian development and maturity stages in the Yellowfin Seabream, Acanthopagrus latus (Teleostei: Sparidae) (Hottuyn, 1782) reared in cages. Kuwait Journal of Science and Engineering, 2003, vol. 30, n. 1, p. 121-137.

AROCHA, F. Oocyte Development and maturity classification of swordfish from The North Western atlantic. Journal of Fish Biology, 2002, vol. 60, p. 13-27.

ASSEM, SS. and EL-ZAEEM, SY. Application of biotechnology in fish breeding ii : production of highly immune genetically modified redbelly Tilapia zilli. African Journal of Biotechnology, 2005, vol. 4, p. 449-459. 
BAZZOLI, N. and RIZZO, E. A comparative cytological and cytochemical study of the oogenesis in ten brazilian teleost fish species. European Archives of Biology, 1990, vol. 101, p. 399-410.

CASSEL, M., MEHANNA, M., MATEUS, L. and FERREIRA, A. Gametogenesis and reproductive cycle of Melanorivulus aff. punctatus (Boulenger, 1895) (Cyprinodontiformes, Rivulidae) in Chapada dos Guimaraes, Mato Grosso, Brazil. Neotropical Ichthyology, 2013, vol. 11, n. 1, p. 179-192.

CEK, S., BROMAGE, N., RANDALL, C. and RANA, K. Oogenesis, hepatosomatic and gonadosomatic index, and sex ratio in rosy barb (Puntius conchonius). Turkish Journal of Fisheries and Aquatic Science, 2001, vol. 1, p. 33-41.

CROWLEY, LELM. and IVANTSOFF, W. Reproduction and early stages of development in two species of Australian rainbowfishes Melanotaenia nigrans and Melanotaenia splendid inornata. Australian Zoologist, 1982, vol. 21, n. 1, p. 85-95.

DE CANALES, GML., BLANCO, M. and SARASQUETE, MC. Carbohydrate and Protein Histochemistry During Oogenesis in Halobatrachus didactylus (Schneider, 1801) from The Bay of Cadiz (Spain). The Histochemical Journal, 1992, vol. 24, p. 337-344.

EL-HALFAWY, M., RAMADAN, AM. and MAHMOUD, WF. Reproductive Biology and Histological Studies of The Grey Mullet Liza Ramada, (Risso, 1982) In Lake Timsah, Suez Canal. Egyptian Journal of Aquatic Research, 2007, vol. 33, n. 1, p. 434-454.

FERREIRA, F., SANTOS, MM., REIS-HENRIQUES, MA., VIEIRA, NM. and MONTEIRO, NM. The annual cycle of oogenesis in The Shanny, Lipophrys pholis (Pisces: Blenniidae). Scientia Marina, 2012, vol. 76, n. 2, p. 273-280.

GARCIA, EL., CHINI, HAS., MAISTRO, JAD. and QUAGIOGRASSIOTTO, I. Dynamic and cytochemistry of oogenesis in Astyanax fasciatus (Cuvier) (Teleostei, Characiformes, Characidae) from Rio Sapucai, Minas Gerais State, Brazil. Revista Brasileira de Zoologia, 2001, vol. 18, n. 4, p. 1057-1064.

INTERNATIONAL UNION FOR CONSERVATION OF NATURE AND NATURAL RESOURCES - IUCN. IUCN red list of threatened species. Version 2013.2. Cambridge: IUCN, 2013. Available from : <www.iucnredlist.org>. Access in: 13 Dec. 2013.

JAYASANKAR, P. and ALAGARSWAMI, K. Histological and histochemical observations on the oocytes in the sand whiting Sillago sihama (Forsskal). Proceedings of the National Academy of Sciences of the United States of America, 1994, vol. B60, n. 2, p. 173-182.

KIMARO, WH. A histologycal and ultrastructural study of gland cells in the ovary of the sexually immature ostrich (Struthio camelus). Asian Journal of Bioologycal Science, 2011, vol. 4, p. 182-188.

LE MENN, F., CERDA, J. and BABIN, PJ. Ultrastructure aspects of the ontogeny and differentiation of ray finned fish ovarian follicles. In BABIN, PJ., CERDA, J. and LUBZENS, E. (Eds.). The fish oocyte: from basic studies to biotechnological applications. New York: Springer, 2007, p. 1-37.

LEFLER, KK., HEGYI, A., BASKA, F., GAL, J., HORVATH, A., URBANYI, B. and SZABO, T. Comparison of ovarian cycles of hungarian riverine fish species representing different spawning strategies. Czech Journal of Animal Science, 2008, vol. 53, n. 10, p. 441-452.

LEVANI-SIVAN, B., VAIMAN, R., SACHS, O. and TZCHORI, I. Spawning induction and hormonal level during final maturation in the silver perch. Aquaculture, 2004, vol. 229, p. 419-431.

LYMAN-GINGERICH, J. and PELEGRI, F. Maternal factor in fish oogenesis and embryonic development. In BABIN, PJ., CERDA, J. and LUBZENS, E. (Eds.). The fish oocyte : from basic studies to biotechnological applications. New York: Springer, 2007. p. 141-174.

MANANGKALAGI, E. Makanan, Pertumbuhan dan Reproduksi Ikan Pelangi Arfak (Melanotaenia arfakensis Allen) di Sungai Nimbai dan Sungai Aimasi, Manokwari. Bogor: Sekolah Pascasarjana Institut Pertanian Bogor, 2009. 105 p. [Thesis].

MUCHLISIN, ZA. A general overview on some aspect of fish reproduction. Aceh International Journal of Science Technology, 2014, vol. 3 , n. 1, p. 43-52.

NASUTION, SH. Karakteristik reproduksi ikan endemik rainbow selebensis (Telmatherina celebensis Boulenger) di Danau Towuti. Journal Penelitian Perikanan Indonesia, Edisi Sumber Daya dan Penangkapan, 2008, vol. 11, n. 2, p. 29-37.

ROCHA, MJ. and ROCHA, E. Morphofunction aspects of reproduction from synchronous to asynchronous fishes : an overview. In REINECKE, M., ZACCONE, G. and KAPOOR, BG. (Eds.). Fish endocrinology. New York: Science Publisher, 2006, p. 571-624.

SANTOS, RN., ANDRADE, CC., SANTOS, AFGN., SANTOS, LN. and ARAUJO, FG. Hystologycal Analysis of Ovarian Development of The Characiform Oligosarkus hepsetus (Cuvier, 1829) in A Brazilian Reservoir. Brazilian Journal of Biology = Revista Brasileira de Biologia, 2005, vol. 65, n. 1, p. 169-177.

SHARMA, RK. and BHAT, RA. Histomorpohology of atretic follicles in rainbow trout (Oncorbynchus mykiss) from Kashmir. Journal of Entomology and Zoology Studies, 2014, vol. 2, n. 4, p. 21-26.

SIBY, LS. Biologi reproduksi ikan Pelangi Merah (Glossolepis incisus Weber 1907) di Danau Sentani. Bogor: Sekolah Pascasarjana Institut Pertanian Bogor, 2009, 70 p. [Thesis].

SINGH, A., SINGH, IJ., RAM, RN. and KUSHWAHA, B. Ovarian development in Labeo dyocheilus (McClelland) during active reproductive phase under captive and wild condition. Journal of Environmental Biology, 2008, vol. 29, n. 2, p. 169-174.

TAPPIN, AR. Rainbowfish fishes, their care o keeping in captivity. Australia: Art Publication, 2010, 493 p.

YON, NDK., AYTEKIN, Y. and YUCE, R. Ovary maturation stages and histologycal investigation of ovary of Zebrafish (Danio rerio). Brazilian Archives of Biology and Technology, 2008, vol. 51, n. 3, p. 513-522. 